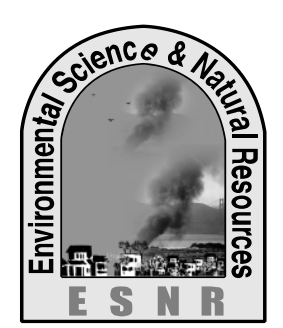

\title{
Effect of Water Management Practices on Rice Yield, Water Productivity and Water Savings under Irrigated Rice Paddy Ecosystem
}

\author{
S. C. Barman ${ }^{1}$, M. A. Ali ${ }^{1 *}$, H. J. Hiya ${ }^{1}$, K. R. Sarker ${ }^{2}$ and M. A. Sattar ${ }^{1}$ \\ ${ }^{1}$ Department of Environmental Science, ${ }^{2}$ Department of Soil Science, \\ Bangladesh Agricultural University, Mymensingh-2202 \\ *Corresponding Author: litonaslam@yahoo.com
}

\begin{abstract}
A field experiment was carried out during the Boro season 2013 to find out the effects of water management practices on rice yield performance and water productivity index at Old Brahmaputra flood plain paddy land, Muktagacha, Mymensingh. The experiment was laid out in randomized complete block design (RCBD) with six (6) irrigation treatments. Two treatments, $\mathrm{T}_{1}$ and $\mathrm{T}_{3}$ were kept under continuous standing water levels ( $10 \mathrm{~cm}$ and $5 \mathrm{~cm}$ respectively) while in treatment $T_{5}$ irrigation water was supplied for $1^{\text {st }} 3$ weeks then followed mid season drain out and re-flooded at flowering stage. Three alternate wetting and drying irrigation treatments, $\mathrm{T}_{2}, \mathrm{~T}_{4}$ and $\mathrm{T}_{6}$ were selected in which irrigation water was applied when water level dropped $20 \mathrm{~cm}, 10 \mathrm{~cm}$ and $15 \mathrm{~cm}$ below ground level, respectively. All the irrigation treatments significantly affected the rice yield and yield contributing parameters. The study revealed that the highest grain yield $\left(5950 \mathrm{~kg} \mathrm{ha}^{-1}\right)$ was found in treatment $T_{5}$ which was identical with AWDI treatment $\mathrm{T}_{4}\left(5820 \mathrm{~kg}^{-1}\right)$ followed by AWDI treatment $\mathrm{T}_{6}\left(5460 \mathrm{~kg} \mathrm{ha}^{-1}\right)$. On the contrary, rice yield of $3350 \mathrm{~kg} \mathrm{ha}^{-1}, 4470 \mathrm{~kg} \mathrm{ha}^{-1}$ and $4810 \mathrm{~kg} \mathrm{ha}^{-1}$ were found in the treatment $\mathrm{T}_{1}$, $\mathrm{T}_{2}$ and $\mathrm{T}_{3}$, respectively. It was found that AWDI treatment $\mathrm{T}_{2}$ showed maximum water savings $(15.1 \%)$ followed by $\mathrm{T}_{6}(11.3 \%), \mathrm{T}_{4}$ $(7.59 \%)$ and $\mathrm{T}_{5}(3.8 \%)$, however rice yield in the treatment $\mathrm{T}_{2}\left(4470 \mathrm{~kg} \mathrm{ha}^{-1}\right)$ was significantly lower compared to $\mathrm{T}_{6}, \mathrm{~T}_{4}$ and $\mathrm{T}_{5}$ treatment. Therefore, it may be inferred that treatment $\mathrm{T}_{4}$ (AWDI; irrigation when water level fell $10 \mathrm{~cm}$ from ground level), $\mathrm{T}_{5}$ (Irrigation for $1^{\text {st }} 3$ weeks, then mid-season drain out and re-flooding at flowering) and $\mathrm{T}_{6}$ (AWDI; irrigation when water level fell $15 \mathrm{~cm}$ from ground level) would be the feasible choice for the water savings, higher rice yield as well as maximum water productivity index $(0.478,0.472$ and 0.467 , respectively) for sustaining rice farming during the dry Boro season in Bangladesh.
\end{abstract}

Key words: AWDI, Productivity, Rice yield and Water savings

\section{Introduction}

Rice Paddy Ecosystem mainly consists of paddy soils, rice plants and natural water body (prolonged/temporarily submergence) or irrigated/rainfed lowland. Water is the vital component of sustainable rice farming in the Asian tropics and subtropics.More than 75 percent of the world's rice is produced under the conventional irrigation practices (i.e., continuous flooding) (Van der Hoek et al., 2001). Rice grown under traditional practices in the Asian tropics and subtropics requires $700-1500 \mathrm{~mm}$ of water per cropping season depending on soil texture (Bhuiyan, 1992). However, this conventional water management method leads to a high amount of surface runoff, seepage, and percolation that can account for 50-80 percent of the total water input (Sharma, 1989). Recently, the scarcity of water has been increasing worldwide. By 2025, the per capita available water resources in Asia are expected to decline by 15-54 percent compared with that of 1990 availability (Guerra et al., 1998). Producing more rice with less water is therefore a formidable challenge for achieving food and water security for these regions (Facon, 2000). Contrary to most lowland rice-growing practices used throughout the world, the rice field is not under continuous flooding but instead is irrigated intermittently during the production period (Van der Hoek et al., 2001).

Alternate Wet and Dry Irrigation (AWDI) is a water management system where rice fields are not kept continuously submerged but are allowed to dry intermittently during the rice growing stages. AWDI can increase the water use efficiency at the field level by reducing seepage and percolation during the production period. Experience with the System of Rice Intensification (SRI) techniques also shows that farmers who grow irrigated rice with continuous flooding have been wasting large volume of water (Uphoff, 2006). The SRI is a production system that emphasize the use of younger seedlings ( $<15$ days) planted singly and at wider spacing, together with the adoption of intermittent irrigation, organic fertilization, and active soil aeration to the extent possible (Stoop et al., 2002; Uphoff, 2007). The SRI system shows that keeping paddy soils moist but not continuously saturated gives better results, both agronomically and economically, than flooding rice throughout its crop cycle. SRI methods enable farmers to reduce their irrigation by 25 $50 \%$ while realizing higher and more profitable production (Uphoff et al., 2002; Anthofer, 2004; Namara et al., 2004; Li et al., 2005; Sato, 2005; Uphoff, 2006). However, good water control and minimal use of water is both the most controversial component in rice farming and the factors most difficult for farmers to regulate. Also, due to the variation in climatic and edaphic factors, results from AWDI methods adopted in one area may not correlate with other areas. The current study, therefore, was undertaken to investigate the effects of alternate wetting and drying irrigation on rice yield, water productivity, soil properties and water savings under boro season field condition.

\section{Materials and Methods}

The field experiment was carried out at Chechua, Muktagacha, Mymensingh. The experiment was laid out in a randomized complete block design (RCBD) having 3 blocks and 6 irrigation treatments. The dimension of an experimental plot was $4.0 \mathrm{~m} \mathrm{x} 2.5 \mathrm{~m}$. 
The plot size was selected based on the facilities available for rice production. The experimental field was prepared by a power tiller and a ladder. It was then fragmented into 3 major blocks. Each block was then divided into 6 experimental plots. Standard recommended doses or fertilizers were used in the experimental plots. Triple superphosphate (TSP), Muriate of potash (MoP), gypsum and zinc sulphate fertilizers were applied only once before transplanting, whereas urea was applied thrice after transplantation. Twenty one days old seedlings of BRRl dhan 28 was transplanted in the field on $10^{\text {th }}$ January, 2013. In this experiment, plots were equipped with a pipe irrigation system, along with water inlet and outlet devices which controlled timely irrigation and drainage. Some pieces of PVC pipes were used to measure the depletion of soil water in the field. The diameter of the PVC pipe was $7.5 \mathrm{~cm}$. Different levels of irrigation were applied to determine the suitable one considering the rice growth Water saving percentage was calculated as follows:

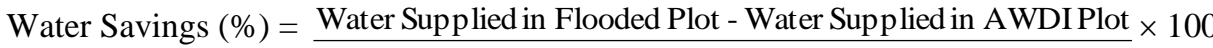
Water Supplied in Flooded Plot

Water Productivity Index was calculated as the ratio of crop yield $\left(\mathrm{kgha}^{-1}\right)$ per unit water $\left(\mathrm{mha}^{-3}\right)$ supplied as Water productivity index $\left(\mathrm{kg} \mathrm{m}^{-3}\right)=\frac{\text { Grain yield }(\mathrm{kg} / \mathrm{ha})}{\text { Total vol. of water supplied }\left(\mathrm{m}^{3} / \mathrm{ha}\right)}$

\section{Results and Discussion}

\section{Water inputs under different irrigation treatments}

During the first 15 days of rice seedling transplantation, $5 \mathrm{~cm}$ standing water was maintained in all the plots to avoid weed infestation (crop establishment period). Water required for crop establishment was estimated $27.2 \mathrm{~cm}$ (Table 1). Thereafter, field plots were irrigated according to irrigation treatments. Treatments $T_{1}$ was and yield and water savings capacity. In each of the cases, the field was allowed to be dried up to a certain level. The depleted water table was observed from the pipes installed in the field. A wooden stick scale was used to measure the water level inside the pipe. The experimental treatments were $\mathrm{T}_{1}=10 \mathrm{~cm}$ standing water maintained $1^{\text {st }} 3$ weeks, then kept $5 \mathrm{~cm}$ throughout the growing season; $\mathrm{T}_{2}=$ Irrigation when water level in the pipe fell $20 \mathrm{~cm}$ below the ground level; $T_{3}=5 \mathrm{~cm}$ standing water maintained throughout the growing season; $\mathrm{T}_{4}=$ Irrigation water when water level fell $10 \mathrm{~cm}$ below ground level; $\mathrm{T}_{5}=$ Irrigation water for $1^{\text {st }} 3$ weeks, then mid-season drain out, re-flooding at flowering; $\mathrm{T}_{6}=$ Irrigation when water level in the pipe fell $15 \mathrm{~cm}$ below the ground level. BRRl dhan 28 was harvested on 18 May 2013 and data on the rice yield and yield contributing parameters were taken before threshing the grains from the plant.

Table 1. Irrigation frequency and water application under different treatments

\begin{tabular}{|c|c|c|c|c|c|c|c|}
\hline Treatments & $\begin{array}{l}\text { No. of } \\
\text { Irrigation }\end{array}$ & $\begin{array}{l}\text { Water for } \\
\text { land } \\
\text { preparation } \\
\text { (cm) }\end{array}$ & $\begin{array}{l}\text { Water for } \\
\text { crop } \\
\text { establishment } \\
(\mathrm{cm})\end{array}$ & $\begin{array}{l}\text { Effective } \\
\text { rainfall } \\
(\mathbf{c m})\end{array}$ & $\begin{array}{l}\text { Total } \\
\text { irrigation } \\
\text { (cm) }\end{array}$ & $\begin{array}{l}\text { Total } \\
\text { volume of water } \\
\text { (L)supplied } \\
/ 10 \mathrm{~m}^{2}\end{array}$ & $\begin{array}{l}\% \\
\text { water } \\
\text { saved }\end{array}$ \\
\hline $\mathrm{T}_{1}$ & 10 & 20 & 27.2 & 34.6 & 131.8 & 13180 & - \\
\hline $\mathrm{T}_{2}$ & 6 & 20 & 27.2 & 34.6 & 111.8 & 11180 & 15.1 \\
\hline $\mathrm{T}_{3}$ & 10 & 20 & 27.2 & 34.6 & 131.8 & 13180 & - \\
\hline $\mathrm{T}_{4}$ & 8 & 20 & 27.2 & 34.6 & 121.8 & 12180 & 7.59 \\
\hline $\mathrm{T}_{5}$ & 9 & 20 & 27.2 & 34.6 & 126.8 & 12600 & 3.8 \\
\hline $\mathrm{T}_{6}$ & 7 & 20 & 27.2 & 34.6 & 116.8 & 11680 & 111.3 \\
\hline
\end{tabular}

- One irrigation means application of $5 \mathrm{~cm}$ water

In our study, higher water saving plots were found under the treatments $\mathrm{T}_{2}, \mathrm{~T}_{4}, \mathrm{~T}_{6}$ and $\mathrm{T}_{5}$ compared to treatment $\mathrm{T}_{1}$. Treatments $\mathrm{T}_{2}, \mathrm{~T}_{4}$ and $\mathrm{T}_{6}$ were selected as AWDI plots. During the rice growing season, the maximum number of irrigations 10, 10, and 9 were given to the plots under the treatments $T_{1}, T_{3}$, and $T_{5}$ respectively, while the treatments $\mathrm{T}_{2}, \mathrm{~T}_{4}$ and $\mathrm{T}_{6}$ received 6,8 and 7 irrigations, respectively (Table1). Higher amount of irrigation water volume was required for the considered to be the control and the plots under this treatments were irrigated continuously throughout the growing season. Plots under the AWDI treatments were irrigated when water level in the perforated pipes dropped to specified depths from the ground surface. The time of water application was indicated by the depletion of water level in the perforated pipes measured from the round surface.

defined by Jaafar et al. (2000). It includes irrigation, rainfall and antecedent soil moisture. 
Keisuke et al. (2007) also reported that irrigation water requirement should be reduced by $20-50 \%$ for nonflooded rice field compared to flooded paddy field. Chapagain et al. (2010) found 29\% saving of irrigation water without reducing grain yield from the AWDI plot compared to conventionally flooded plot.

\section{Effect of irrigation treatments on yield and yield contributing parameters}

\section{Effect on number of effective tillers per Panicles}

Table 2 shows that the effect of irrigation treatments on number of panicles was significant at 1 percent level of probability. The highest number of panicles (15.41) per hill was found in treatment $\mathrm{T}_{5}$ and the number consistently decreased in treatments $\mathrm{T}_{6}$ (15.21), $\mathrm{T}_{4}$ (14.34), $\mathrm{T}_{3}$ (12.20), $\mathrm{T}_{2}(10.64)$ and $\mathrm{T}_{1}(7.09)$ as shown in Table 2. The results showed that the number of panicles per hill in the AWDI treatments $\left(\mathrm{T}_{4}, \mathrm{~T}_{5}\right.$ and $\left.\mathrm{T}_{6}\right)$ increased significantly compared to other treatments.

\section{Effect on panicle length}

The experimental results showed that there was no significant effects among the treatments on panicle length. Treatment T1 showed lower panicle length compared to other treatments which might be the insufficient photosynthesis from less vigorous crop canopy having reduced leaf area (Table 2).

\section{Effect on number of filled grains per panicle}

Table 2 shows that the number of filled grains per panicle increased consistently in the AWDI treatments. However, in this parameter $\mathrm{T}_{5}$ (168.99) was significantly different from $\mathrm{T}_{4}(140.49), \mathrm{T}_{6}(133.14), \mathrm{T}_{3}$ (101.70), $\mathrm{T}_{2}$ (90.58) and $\mathrm{T}_{1}(86.82)$.

\section{Effect on 1000-grain weight}

The highest 1000 -grain weight $(24.81 \mathrm{~g})$ was obtained in treatment $\mathrm{T}_{5}$ followed by treatments $\mathrm{T}_{2}(24.76 \mathrm{~g}), \mathrm{T}_{6}$ $(24.09 \mathrm{~g}), \mathrm{T}_{1}(23.93 \mathrm{~g}), \mathrm{T}_{4}(23.87 \mathrm{~g})$ and $\mathrm{T}_{3}(23.43 \mathrm{~g})$. Table 2 shows that the variations in different treatments are not statistically significant.

\section{Effect on percentage of ripened grains}

The highest percentage of ripened grains (92.50) was obtained in treatment $\mathrm{T}_{5}$ followed by treatment $\mathrm{T}_{4}$ (87.81), $\mathrm{T}_{6}$ (85.42), $\mathrm{T}_{3}$ (81.62), $\mathrm{T}_{2}$ (80.25) and $\mathrm{T}_{1}$ (76.73). Table 2 shows that the variations in different treatment.

Effect of irrigation treatments on grain yield

Grain yield was significantly influenced by irrigation water treatments. The highest grain yield $\left(5950 \mathrm{~kg} \mathrm{ha}^{-1}\right)$ was obtained in the treatment $\mathrm{T}_{5}$, whereas the AWDI treatment $\mathrm{T}_{4}$ gave grain yield $\left(5820 \mathrm{~kg} \mathrm{ha}^{-1}\right)$ which was statistically similar to the yield in $\mathrm{T}_{5}$ treatment. Again AWDI treatment $\mathrm{T}_{6}$ also gave the satisfactory yield $\left(5460 \mathrm{~kg} \mathrm{ha}^{-1}\right)$ compared to other treatments. The lowest yield was found in continuously flooded treatment $T_{1}$ (3350 kg ha ${ }^{-1}$ ) followed by AWDI treatment $T_{2}$ (Irrigation when water level fall $20 \mathrm{~cm}$ from the ground level) $\left(4470 \mathrm{~kg} \mathrm{ha}^{-1}\right)$ that might be due to more stress. Khan et al. (2015) found that AWDI treatment showed $18 \%$ more grain yield in BRRI dhan-28 and $22 \%$ more grain yield in BINA dhan-8 compared to different irrigation treatments. Chapagain et al. (2011) reported that rice grain yield was $7.8 \mathrm{t} / \mathrm{h}$ from the conventionally flooded plot compared to AWDI plot $\left(7.2 \mathrm{th}^{-1}\right)$, but required more water.

\section{Effect of irrigation treatments on straw yield}

Variation in straw yield under different treatments is shown in Table 2. Straw yields under different irrigation treatments were significantly different at 1 percent level of probability (Table 2). However, the straw yield difference between $\mathrm{T}_{2}$ and $\mathrm{T}_{3}$ is not statistically significant. This revealed that the straw yield was affected by different levels of irrigation. The highest yield was obtained from treatment $\mathrm{T}_{4}$ (5930 $\left.\mathrm{kgha}^{-1}\right)$ followed by $\mathrm{T}_{5}\left(5890 \mathrm{~kg} \mathrm{ha}^{-1}\right), \mathrm{T}_{6}\left(5810 \mathrm{kgha}^{-1}\right)$, $\mathrm{T}_{2}\left(5490 \mathrm{kgha}^{-1}\right), \mathrm{T}_{3}\left(5120 \mathrm{~kg} \mathrm{ha}^{-1}\right)$ and $\mathrm{T}_{1}$ (4340 kgha $\left.{ }^{1}\right)$. Since the straw yield is the function of plant height and number of effective tillers, treatments resulting higher number of tillers and greater plant heights produced higher straw yield.

\section{Effect on harvest index (HI)}

The experiment showed that different levels of irrigation did not have any significant effect on the harvest index. The highest value of harvest index $(55.92 \%)$ was found for the treatment $\mathrm{T}_{5}$, which was statistically similar to those obtained in treatments $\mathrm{T}_{4}$ (49.53\%) (Table 2).

\section{Effect on water productivity index}

The highest water productivity index $(0.478 \mathrm{kgm}-3)$ was obtained in treatment $\mathrm{T}_{4}$ followed by treatments $\mathrm{T}_{5}$ $\left(0.472 \mathrm{~kg} \mathrm{~m}^{-3}\right), \mathrm{T}_{6}\left(0.467 \mathrm{~kg} \mathrm{~m}^{-3}\right), \mathrm{T}_{2}\left(0.399 \mathrm{~kg} \mathrm{~m}^{-3}\right), \mathrm{T}_{3}$ $\left(0.364 \mathrm{~kg} \mathrm{~m}^{-3}\right)$ and $\mathrm{T}_{1}\left(0.254 \mathrm{~kg} \mathrm{~m}^{-3}\right)$ (Fig. 1). Water productivity index for the treatments $\mathrm{T}_{4}, \mathrm{~T}_{5}$ and $\mathrm{T}_{6}$ were statistically similar in the present study. 
Table 2. Effect of different irrigation treatments on the yield and yield contributing parameters of rice (BRRI dhan 28)

\begin{tabular}{|c|c|c|c|c|c|c|c|c|c|c|}
\hline Treatments & $\begin{array}{c}\text { Plant height } \\
(\mathrm{cm})\end{array}$ & $\begin{array}{l}\text { Tiller } \\
\text { plant }^{-1}\end{array}$ & $\begin{array}{c}\text { No of } \\
\text { panicles } \\
\text { plant }^{-1}\end{array}$ & $\begin{array}{c}\text { Panicle } \\
\text { length }(\mathrm{cm})\end{array}$ & $\begin{array}{c}\text { Filled } \\
\text { Grainpanicle }^{-1}\end{array}$ & $\begin{array}{c}\% \text { Ripened } \\
\text { grains }\end{array}$ & 1000-GW (g) & $\begin{array}{c}\text { Grain } \\
\text { Yield } \\
\left(\mathrm{kgha}^{-1}\right)\end{array}$ & $\begin{array}{c}\text { Straw } \\
\text { Yield }\left(\mathrm{kgha}^{-1}\right)\end{array}$ & $\underset{(\%)}{\text { HI }}$ \\
\hline $\mathrm{T}_{1}$ & $79.96 \mathrm{~b}$ & $11.20 \mathrm{~d}$ & $7.09 \mathrm{e}$ & $20.09 \mathrm{~b}$ & $86.82 \mathrm{e}$ & 76.73 & 23.93 & $3350 \mathrm{e}$ & $4340 d$ & $43.56 \mathrm{~b}$ \\
\hline $\mathrm{T}_{2}$ & $81.08 \mathrm{a}$ & $12.53 \mathrm{c}$ & $10.64 d$ & $22.30 \mathrm{a}$ & $90.58 \mathrm{e}$ & 80.25 & 24.76 & $4470 \mathrm{~d}$ & $5490 \mathrm{~b}$ & $44.87 \mathrm{~b}$ \\
\hline $\mathrm{T}_{3}$ & $81.95 \mathrm{a}$ & $13.91 \mathrm{~b}$ & $12.20 \mathrm{c}$ & $22.85 \mathrm{a}$ & $101.70 \mathrm{~d}$ & 81.62 & 23.43 & $4810 \mathrm{c}$ & $5120 \mathrm{c}$ & $48.44 \mathrm{~b}$ \\
\hline $\mathrm{T}_{4}$ & $82.50 \mathrm{a}$ & $16.35 \mathrm{a}$ & $14.34 \mathrm{ab}$ & $22.22 \mathrm{a}$ & $140.49 \mathrm{c}$ & 87.81 & 23.87 & $5820 \mathrm{a}$ & $5930 a$ & $49.53 b$ \\
\hline $\mathrm{T}_{5}$ & $82.33 a$ & $14.64 \mathrm{~b}$ & $15.41 \mathrm{a}$ & $22.95 \mathrm{a}$ & $168.99 a$ & 92.50 & 24.81 & $5950 \mathrm{a}$ & $5890 \mathrm{~b}$ & $55.92 \mathrm{a}$ \\
\hline $\mathrm{T}_{6}$ & $82.97 \mathrm{a}$ & $16.52 \mathrm{a}$ & $15.21 \mathrm{~b}$ & $22.55 \mathrm{a}$ & $133.14 b$ & 85.42 & 24.09 & $5460 \mathrm{~b}$ & $5810 \mathrm{~b}$ & $48.44 b$ \\
\hline $\mathrm{CV}(\%)$ & 3.63 & 5.34 & 5.04 & 3.07 & 6.11 & 4.99 & 3.39 & 10.47 & 5.89 & 6.35 \\
\hline LSD & 1.957 & 1.155 & 0.23 & 1.332 & 4.13 & 3.27 & - & 152.41 & 45.66 & 0.971 \\
\hline Level of Sig. & $* *$ & $* *$ & $* *$ & $*$ & $* *$ & $* *$ & NS & $* *$ & $* *$ & $* *$ \\
\hline
\end{tabular}

- $\mathrm{T}_{1}=10 \mathrm{~cm}$ standing water maintained $1^{\text {st }} 3$ weeks, then kept $5 \mathrm{~cm}$ throughout the growing season;

- $\mathrm{T}_{2}=$ Irrigation when water level in the pipe fell $20 \mathrm{~cm}$ below the ground level;

- $\mathrm{T}_{3}=5 \mathrm{~cm}$ standing water maintained throughout the growing season;

- $\mathrm{T}_{4}=$ Irrigation water when water level fell $10 \mathrm{~cm}$ below ground level;

- $\mathrm{T}_{5}=$ Irrigation water for $1^{\text {st }} 3$ weeks, then mid season drain out, re-flooding at flowering

- $\mathrm{T}_{6}=$ Irrigation when water level in the pipe fell $15 \mathrm{~cm}$ below the ground level. 


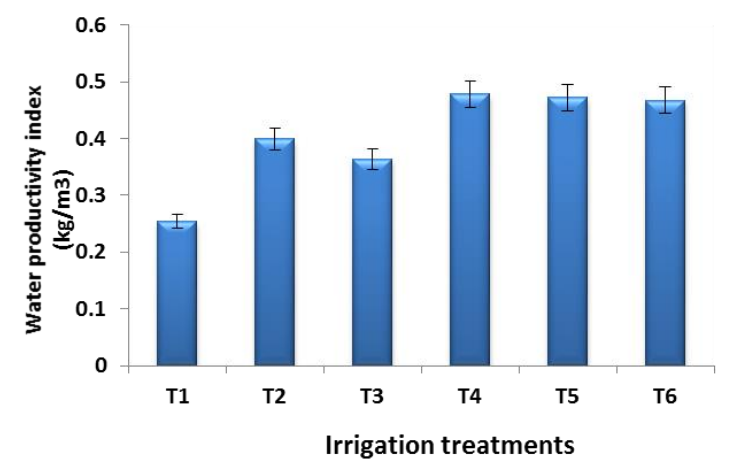

Fig. 1. Water productivity index under different Tejendra et al. (2011) reported that water productivity index was significantly greater in the AWDI plot $1.7 \mathrm{~kg}$ $\mathrm{m}^{-3}$ compared to conventional irrigated plot $1.3 \mathrm{~kg} \mathrm{~m}^{-3}$

\section{Conclusions}

The alternate wetting and drying irrigation treatments significantly affected the rice yield and water productivity. The results revealed that the highest grain yield $\left(5950 \mathrm{~kg} \mathrm{ha}^{-1}\right.$ ) was found in the treatment $\mathrm{T}_{5}$, which was very close to the yield $\left(5820 \mathrm{~kg} \mathrm{ha}^{-1}\right)$ obtained in AWDI treatment $\mathrm{T}_{4}$ followed by AWDI treatment $\mathrm{T}_{6}\left(5460 \mathrm{~kg} \mathrm{ha}^{-1}\right)$. In the present study, treatments $\mathrm{T}_{5}, \mathrm{~T}_{4}$ and $\mathrm{T}_{6}$ appeared to produce the best output considering the yield of rice grain as well as water saving percentages compared to other treatments. It was also observed that plant height, number of panicles per hill, grain yield, harvest index and water productivity index were higher in AWDI plots $\left(\mathrm{T}_{4}\right.$ and $\mathrm{T}_{6}$ ) and in treatment $\mathrm{T}_{5}$ plot compared to other treatments. Therefore, it may be inferred that practicing AWDI treatments $\mathrm{T}_{4}$ (irrigated when water level fell $10 \mathrm{~cm}$ ), $\mathrm{T}_{5}$ (Irrigation $1^{\text {st }} 3$ weeks with mid-season drain out and re-flooding at flowering) and $\mathrm{T}_{6}$ (irrigated when water level fell $15 \mathrm{~cm}$ ) would be the feasible choice for farmers to obtain optimum grain yield with higher water productivity index irrigation treatments.

\section{References}

Anthofer, J. 2004. Evaluation of the System of Rice Intensification (SRI) in Combodia. [Online] Available: http://www.tropentag. de/2004/abstracts/full/399.pdf.

Bhuiyan, S. I. 1992. Water management in relation to crop production: Case study in rice. Outlook on Agriculture, 21: 293-299.

Chapagain, T. and Yamaji. E. 2010. The effect of irrigation method, age of seedling and spacing on crop performance, productivity and water wise rice production in Japan. Paddy Water Environ., 8(1): 81-90.

Facon, T. 2000. Improving the irrigation service to farmers: a key issue in participatory irrigation management. Paper presented at the Asian Productivity Organization Seminar on Organizational Change for Participatory Irrigation Management, 23-27, Manila, Philippines.
Guerra, L. C.; Bhuiyan, S. I.; Tuong, T. P. and Barker, R. 1998. Producing rice with less water from irrigated systems. SWIM Paper 5. Sri-Lanka, Colombo: International Irrigation Management Institute.

Jaafar, M. N.; Saad, P. and Vel Arjunan, S. N. 2000. A computational model for water use efficiency in rice production. J.Teknologi Maklumat, 12(1): 1-13.

Keisuke, S.; Yamaji, E.; Sato, S.; Budhiharto, P. S. and Mizoguchi, M. 2007. Sustainability of System of Rice Intensification: Benefits of SRI focusing on effects of intermittent irrigation on yield increase and water savings. In: Proceeding of PAWEES 2007 $6^{\text {th }}$ International Conference on Sustainable Rural Development and Management (pp.25-37), 18 October 2007. South Korea: Seoul National University.

Khan, M. A.; Reza, M. O. H.; Khan, M. T. and Ali, M. A. 2015. Effect of irrigation water management practices and rice cultivars on methane $\left(\mathrm{CH}_{4}\right)$ emission and rice productivity, International Journal of Innovation and applied studies, 10(2): 516-534.

Namara, R. E.; Weligamage, P. and Barker, R. 2004. Prospects for Adopting System of Rice Intensification in Sri Lanka: A Socioeconomic Perspective. IWMI Research Paper 75. Colombo: International Water Management Institute (IWMI).

Singh, C. B.; Aujla, T. S.; Sandhu, B. S. and Khera, K. L. 1996. Effects of transplanting data and irrigation regime on growth, yield and water use in rice (Oryza sativa) in northern India. Indian Journal of Agricultural Sciences, 66: 137-141.

Sharma, P. K. 1989. Effect of period moisture stress on water-use efficiency in wetland rice. Oryza. 26: 252-257.

Smith, M. 1992. CROPWAT-A computer programme. Irrigation Planning and Management. FAO Irrigation and Drainage Paper 46. Rome, Italy.

Stoop, W. A.; Uphoff, N. and Kassam, A. 2002. A review of agricultural research raised by the system of rice intensification (SRI) from Madagascr: Opportunities for improving farming systems for resource-poor farmers. Agricultural Systems, 71: 249-274.

Sato, S. 2005. System of Rice Intensification (SRI): 3 Years' experience of SRI practice under DISIMP. Paper for Workshop of Integrated Citarum Water Management Project, 4-5 July 2005, Jakarta: Nippon Koei Consultancy Office.

Tabbal, D. F.; Lampayan, R. M. and Bhuiyan, S. I. 1999. Water-efficient irrigation technique for rice. In V. V. N. Murty, K. Koga (Eds.), Soil and water engineering for paddy field management. Proceedings of the International Workshop on Soil and Water Engineering for Paddy Field Management, 28-30 January. Bangkok, Thailand: Asian Institute of Technology.

Tejendra, T.; Andrew, R. and Eiji, Y. 2011. Achieving More with Less Water: Alternate Wet and Dry Irrigation (AWDI) as an Alternative to the 
Conventional Water Management Practices in Rice Farming. Paddy and Water Environment, 9(1): 5364.

Uphoff, N. and Randriamiharisoa, R. 2002. Reducing water use in irrigated rice production with the Madagascar System of Rice Intensification (SRI). In: Bouman et al. (Eds.). Water wise Rice Production. pp. 71-78. Los Banos: International Rice Research Institute (IRRI).

Uphoff, N. 2006. System of Rice Intensification (SRI) as a methodology for reducing water requirements in irrigated rice production. Paper for International Dialogue on Rice and Water Exploring Options for Food Security and Sustainable Environments, held at IRRI, Los Banos, Philippines.
Uphoff, N. 2007. The System of Rice Intensification: Using alternative cultural practices to increase rice production and profitability from existing yield potentials. International Rice Commission Newsletter, Number 55, U.N. Food and Agriculture Organization, Rome.

Van der Hoek, W.; Sakthivadivel, R.; Renshaw, M.; Silver, J. B.; Birley, M. H. and Konradsen, F. 2001. Alternate wet/dry irrigation in rice cultivation: A practical way to save water and control malaria and Japanese encephalitis? Research Report 47, Colombo: International Water Management Institute. 